\title{
Analysis of Behaviors and Attitudes of Bread Consumption in Turkey: Case of the Province of Adana
}

\author{
Şinasi Akdemir ${ }^{*}$, Fersin Keskin ${ }^{2}$, Hazer Ünal ${ }^{3}$, Yann Miassi ${ }^{4}$ \\ ${ }^{1}$ Department of Agricultural Economics, Faculty of Agriculture, University of Cukurova, 01330 Balcalı, Adana, Turkey (0000-0002-4088-8775) \\ ${ }^{2}$ Ministry of Agriculture and Livestock, Ankara, Turkey (0000-0002-3499-8388) \\ ${ }^{3}$ Department of Agricultural Economics, Faculty of Agriculture, University of Cukurova, 01330 Balcal1, Adana, Turkey (0000-0002-0915-1679) \\ ${ }^{4}$ Department of Agricultural Economics, Faculty of Agriculture, University of Cukurova, 01330 Balcal1, Adana, Turkey (0000-0003-3835-670X)
}

(First received 7 May 2020 and in final form 10 July 2020)

(DOI: $10.31590 /$ ejosat.733594)

ATIF/REFERENCE: Akdemir, Ş., Keskin, F., Ünal, H \& Miassi, Y. (2020). Analysis of Behaviors and Attitudes of Bread Consumption in Turkey: Case of the Province of Adana. European Journal of Science and Technology, (19), $659-667$.

\begin{abstract}
The objective of this study was to analyze the behavior and attitudes of bread consumers in Turkey in the province of Adana. The surveys were carried out in a simple random fashion among 100 households in the city center of Adana province according to social class. Analysis of the data collected shows that the behavior and attitudes of bread consumers in the province of Adana have changed over time not only in terms of quantity, types of bread and places of purchase. This change in behavior and attitudes is influenced by socio-economic and demographic characteristics such as education, occupation, household size, social class and monthly income of consumers. The increase in the unit selling price of bread significantly influences consumer behavior and attitudes. In a context where bread represents a basic foodstuff for a large part of the population, it is therefore important to develop policies so that bread is accessible to all.
\end{abstract}

Keywords: Adana, bread consumption, consumer attitudes, consumer behavior, Turkey.

\section{Türkiye'deki Ekmek Tüketicilerinin Davranış ve Tutumları: Adana İli Örneği}

$\ddot{O} \mathbf{z}$

Bu çalışmanın amacı, Adana ilinde ekmek tüketicilerinin davranış ve tutumlarını incelemektir. Araştırmanın anketleri sosyal sınıflara göre basit rastgele bir şekilde seçilen Adana il merkezindeki 100 hanede 2020 yılında gerçekleştirilmiştir. Araştırma sonuçları; Adana ilinde son yıllarda tüketicilerin ekmek tüketim miktarları, tükettikleri ekmek çeşitleri ile ekmek satın alma yerleri açısından önemli değişim gösterdiği, bu değişimde; tüketicilerin eğitim düzeyi, mesleği, hane halkı büyüklüğü ve aylık gelirinin etkili olduğu, tüketiclerin tam buğday ekmek çeşidine daha yüksek fiyat ödemeye istekli olduğu ortaya konmuştur.

Anahtar Kelimeler: Adana, ekmek tüketimi, tüketici davranışı, tüketici tutumları, Türkiye.

\section{Introduction}

Food consumption patterns vary from country to country or region to region. In general, the most recurrent models are the Western Food Consumption models and then the Japanese one. The Japanese consumption model is mainly based on consumption of

\footnotetext{
* Corresponding Author: Department of Agricultural Economics, Faculty of Agriculture, University of Cukurova, 01330 Balcal1, Adana, Turkey (0000-0002-4088-8775), sinasi.akdemir@gmail.com
} 
fish and seafood (AAFC, 2014). Contrary to this model, the Western Food Consumption model is characterized by the predominance of cereals and roots, supplemented by proteins originating in particular from legumes (Delgado, 1999). Some countries adopt one or the other of these models, while others only partially adopt one of these models. In other words, these models are sometimes adopted with a few modifications.

Turkey is one of the countries that has opted for a traditional agricultural consumption model based on wheat consumption (Padilla, 2001; Marty et al, 2015). All from a much older era when wheat was taxed in certain countries including Turkey by the Romans (Padilla, 2001). The cereal contribution to the vegetable food supply of Turkey and the Near East is mainly due to wheat (Marty et al, 2015). This partially justifies the high level of bread consumption in Turkey (Erturk \& Arslanta, 2015).

Bread is a highly consumed food in households around the world; in both developed and developing countries. However, it should be noted that the level of consumption is much higher among households in developing countries. The level of consumption varies from one country to another. However, Turkey is one of those countries where the level of annual per capita consumption is among the highest. Annual bread consumption per capita is $45 \mathrm{~kg}$ in Denmark, Belgium and Russia $55 \mathrm{~kg}$, $56 \mathrm{~kg}$ in Germany, $57 \mathrm{~kg}$ in France, $89 \mathrm{~kg}$ in Ukraine and $104 \mathrm{~kg}$ in Turkey (Anonymous, 2016). According to, Koten \& Unsal (2004), the importance of bread for Turkish households is due to the fact that it is an easily accessible and inexpensive food, and can be eaten with many foods because it has a neutral taste and aroma. Bread is an important source of energy and nutrients for the body (Baysal, 2011; Guine et al., 2016). The consumption of $400 \mathrm{~g}$ of whole meal bread covers between 51 to $55 \%$ of daily protein needs, 16 to $62 \%$ of iron needs, 12 to $74 \%$ of calcium, 35 to $82 \%$ of vitamin B1, 16 to $39 \%$ of vitamin B2, 20 to 39\% niacin (Dogan, 2003).

Previously, teachers were sent to rural areas of Turkey to educate the children there. At one time, the bran and germs of whe at were used for animal feed; which gave the bread a blackish color. Given the fact that the inhabitants of these rural areas opted for the preparation of white bread, these teachers exchanged their whole black bread imported from the city center by taking the white bread produced by the inhabitants of the village. As a result, black bread was gradually abandoned, giving way to white bread. But nowadays, given the fact that the goods made from the consumption of whole meal bread are traced in the literature and are strongly advised by an innumerable number of dieticians and researchers, the consumption of whole meal bread has become more and more important in Turkey. With the fall in wheat production in recent years (FAOSTAT, 2020), then the perpetual dynamism of the socioeconomic and demographic characteristics of households (TUIK, 2020), one wonders what it would be the repercussions of all of these parameters on attitudes and behavior of bread consumption in Turkey. According to Uzundumlu et al. (2018), socio-economic characteristics influence attitudes and behavior in the consumption of bread in Turkey, precisely in the region of Erzurum.

There are several works such as those of Aksoylu et al., (2004), Ertürk \& Arslanta (2015), then of Uzundumlu et al., (2018) on the study of the level of bread consumption and attitudes and behaviors of consumption of bread in households in different cities of Turkey. But very few of these works were part of a study over time in order to better understand the changes. The present work analyzes both past and present consumer attitudes and behaviors in order to study possible changes.

\section{Methodology}

This research focused on households in the center of the city of Adana in order to analyze their behavior and attitudes regarding the consumption of bread. Information was collected during the first quarter of 2020 on a simple random sample of 100 households. The study was conducted taking into account all social classes: the wealthy class, the middle class and those of the lowest income. In order to study in depth, the possible changes, with all the data collected, a comparison was made between current behaviors and attitudes with those of the consumer in the past. The term "past" refers to the period before the change in consumer behavior. It varies from one consumer to another. The data collected focused mainly on the socio-economic characteristics of consumers, the frequency of bread consumption, the types of bread consumed, the criteria guiding them in the choice of places of purchase, as well as their perception in relation to the consumption of bread.

SPSS software made it possible to establish all the descriptive statistics necessary for the comparisons. A linear regression model was performed in order to analyze the parameters influencing the consumption of bread. In this analysis, the relationship between the total number of breads currently consumed and the total bread consumed in the past was taken as the dependent variable. Subsequently, two different logistic regression models with a view to analyzing the effect of the change in the unit price of bread on the consumer's willingness to buy was evaluated by the consumer's decision to buy whole wheat bread whole, although expensive by $5 \%$ or $10 \%$. This decision by the consumer representing the dependent variable was introduced as in binary form taking the value 1 if the consumer answers with " yes" and by 2 if he answers with " no". In each of these cases, a regression model was performed.

\section{Results and Discussion}

\subsection{Socio-economic characteristics of consumers}

The socio-demographic characteristics of consumers are presented in Table 1. The average age of the respondents in downtown Adana is 45 years. $56 \%$ of this population is made up of men, $92 \%$ of them have social security cover, most of them have university education (53\%) and are mainly civil servants from the private and public sectors $(63 \%)$. Only $6 \%$ have a level lower than or equal to that of the primary level. The average monthly income of this population is $7931 \mathrm{TL}$.

Households have on average less than one (1) child (infants, pre-adolescent), approximately one (1) young person (adolescent), then three (3) adults. About 50\% of households have neither child (65\%) nor adolescents (55\%). This justifies the reason why the majority of households are made up of adults. Within their households, there is on average minus about one (1) person whose 
European Journal of Science and Technology

occupation requires the use of physical force. In fact, $62 \%$ of households have at least three (3) people doing physical work on average. All of these data are reported in Table 1.

Table 1. Socio-economic characteristics of consumers

\begin{tabular}{|c|c|c|c|}
\hline Variables & & Percentage & Average \\
\hline \multirow{4}{*}{ Age } & $18-35$ & 23 & 29,5 \\
\hline & $36-50$ & 44 & 44,1 \\
\hline & $51-75$ & 33 & 59,2 \\
\hline & Total & 100 & 45,7 \\
\hline \multirow{3}{*}{ Sex } & Man & 56 & - \\
\hline & Women & 44 & - \\
\hline & Total & 100 & - \\
\hline \multirow{3}{*}{ Social Security } & Exist & 92 & - \\
\hline & Does not exist & 8 & - \\
\hline & Total & 100 & - \\
\hline \multirow{4}{*}{ Number of children } & 0 & 65 & 0 \\
\hline & $01-02$ & 28 & 1,5 \\
\hline & $03-04$ & 7 & 3,2 \\
\hline & Total & 100 & 0,6 \\
\hline \multirow{4}{*}{ Number of young } & 0 & 55 & 0 \\
\hline & $01-02$ & 35 & 1,4 \\
\hline & $03-04$ & 10 & 4 \\
\hline & Total & 100 & 0,9 \\
\hline \multirow{4}{*}{ Number of adults } & $01-02$ & 28 & 1,7 \\
\hline & $03-04$ & 53 & 3,6 \\
\hline & $05-13$ & 19 & 6,3 \\
\hline & Total & 100 & 3,6 \\
\hline \multirow{4}{*}{ Level of education } & Primary and lower level & 6 & - \\
\hline & Secondary level & 41 & - \\
\hline & University level & 53 & - \\
\hline & Total & 100 & - \\
\hline \multirow{3}{*}{ Link with the rural environment } & Exist & 43 & - \\
\hline & Does not exist & 56 & - \\
\hline & Total & 100 & - \\
\hline \multirow{4}{*}{ Profession } & Farmer & 20 & - \\
\hline & Trader & 15 & - \\
\hline & State and private official & 63 & - \\
\hline & Total & 100 & - \\
\hline \multirow{4}{*}{$\begin{array}{l}\text { Number of people performing } \\
\text { physical work }\end{array}$} & 0 & 37,3 & 0 \\
\hline & 1 & 43,4 & 1 \\
\hline & 2 and more & 19,1 & 2,2 \\
\hline & Total & 100 & 0,8 \\
\hline \multirow{4}{*}{ Monthly income } & $2000-4000 \mathrm{TL}$ & 26 & 3192,3 \\
\hline & $4001-9000 \mathrm{TL}$ & 42 & 6502,3 \\
\hline & Plus de $9001 \mathrm{TL}$ & 32 & 13656,2 \\
\hline & Total & 100 & 7931 \\
\hline
\end{tabular}

\subsection{General trends in bread consumption}

\subsubsection{Average daily bread consumption}

The data collected made it possible to present a general trend in the daily consumption of bread by households in the province of Adana in terms of quantity. More specifically, a comparison of the level of household bread consumption in the past and the present was made (Table 2). Analysis of the results shows that average daily household consumption has dropped from around 3.22 to 2.79 baguettes, a drop of $13.35 \%$. According to Bouteldja (2014), the consumption of bread is also constantly decreasing in France. More specifically, in downtown Adana, consumption of white bread has decreased by $24.21 \%$ (from 1.90 to 1.44 ). Unlike white bread, the consumption of whole meal wheat bread and that of non-whole meal bread increased by $115.38 \%$ and $100.0 \%$ respectively. 
Table 2. Level of bread consumption according to types (number / household / day)

\begin{tabular}{lrrr}
\hline Types of bread & $\begin{array}{r}\text { Types of } \\
\text { bread }\end{array}$ & Types of bread & Types of bread \\
\hline White & 1,90 & 1,44 & $-24,21$ \\
\hline whole wheat bread & 0,26 & 0,56 & 115,38 \\
\hline Loaf of bread & 0,02 & 0,04 & 100,50 \\
\hline Loaf of bread & 0,92 & 0,50 & $-45,65$ \\
\hline Consumption outside the home & 0,12 & 0,25 & 08,33 \\
\hline Total bread consumption & 3,22 & 2,79 & $-13,35$ \\
\hline
\end{tabular}

Since consumers were asked about their level of bread consumption (in the past and currently) in terms of quantity, a t-test for paired sample was carried out to check if there is a statistical difference between the total consumption past bread and the current one (Table 3). The consumption of bread in terms of quantity between the past and the present has reduced by 0.52 baguette bread (1 bread $=429 \mathrm{~g}$ ). We therefore contact Adana households currently consuming half a baguette less than in the past. According to the test carried out, this difference is statistically significant, since the probability obtained is less than $1 \%(\mathrm{p}=0.00)$. As a result, less bread is consumed today than in the past.

Table 3. $\mathrm{T}$ test result

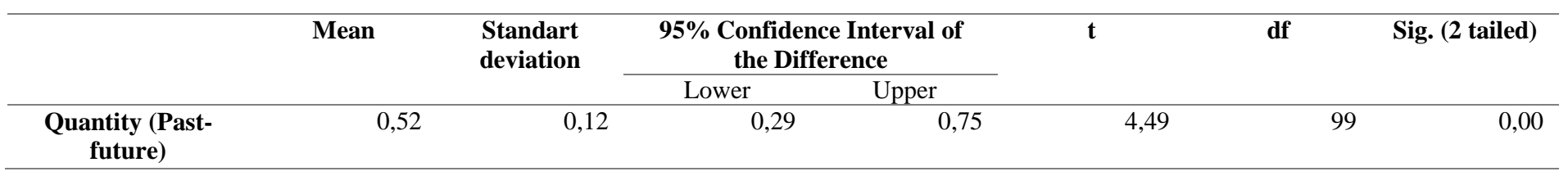

In order to study over time, the types of bread adopted and consumed by Adana households, they were asked to assign scores ranging from 1 to 5 depending on the level of consumption of each type of bread. The score 1 indicates the type of bread very little consumed, then 5 when it is very consumed. The scores obtained were translated into a percentage and then average score calculations were carried out. A comparison was made between current and past consumption levels.

Table 4. Types of bread

\begin{tabular}{lrrrrrrrrrrrrrrr}
\hline & \multicolumn{1}{c}{ In the past (\%) } & \multicolumn{1}{c}{ Currently (\%) } & \multicolumn{1}{c}{$\begin{array}{c}\text { Average } \\
\text { difference }\end{array}$} \\
$\begin{array}{l}\text { Types of } \\
\text { bread }\end{array}$ & $\mathbf{1}$ & $\mathbf{2}$ & $\mathbf{3}$ & $\mathbf{4}$ & $\mathbf{5}$ & $\mathbf{N}$ & Mean & $\mathbf{1}$ & $\mathbf{2}$ & $\mathbf{3}$ & $\mathbf{4}$ & $\mathbf{5}$ & $\mathbf{N}$ & Mean \\
\hline White & 8,0 & 5,7 & 5,7 & 11,4 & 68,9 & 100,0 & 4,2 & 18,6 & 10,4 & 10,4 & 6,9 & 53,4 & 100,0 & 3,6 \\
\hline $\begin{array}{l}\text { Whole } \\
\text { wheat }\end{array}$ & 40,6 & 20,3 & 11,8 & 15,2 & 11,8 & 100,0 & 2,3 & 9,2 & 14,4 & 9,2 & 5,7 & 1,3 & 100,0 & 3,8 \\
\hline $\begin{array}{l}\text { Bread } \\
\text { from the } \\
\text { village }\end{array}$ & 27,0 & 14,5 & 18,7 & 31,2 & 8,3 & 100,0 & 2,7 & 16,9 & 20,7 & 24,5 & 26,4 & 11,3 & 100,0 & 2,9 \\
\hline $\begin{array}{l}\text { Pide- } \\
\text { Lavash }\end{array}$ & 6,0 & 12,1 & 27,2 & 24,2 & 30,3 & 100,0 & 3,6 & 8,3 & 18,0 & 30,5 & 27,7 & 15,2 & 100,0 & 3,2 \\
\hline $\begin{array}{l}\text { Tost- } \\
\text { Sandwich }\end{array}$ & 54,2 & 25,7 & 11,4 & 5,7 & 2,8 & 100,0 & 1,7 & 37,8 & 27,0 & 24,3 & 8,1 & 2,7 & 100,0 & 2,1 \\
\hline $\begin{array}{l}\text { Oven- } \\
\text { baked }\end{array}$ & 16,3 & 14,5 & 14,5 & 21,8 & 32,7 & 100,0 & 3,4 & 16,6 & 23,3 & 23,3 & 15,0 & 21,6 & 100,0 & 3,0 \\
\hline
\end{tabular}

Analysis of the statistics obtained shows that in the past, white bread was the most consumed (average score of 4.2) (Table 4). This type of bread has been replaced today by whole wheat bread (average score of 3.8). White bread is prepared from wheat flour from which the bran and germs have been removed, which gives the bread a white color; while whole meal bread is made from whole wheat flour (Curtet, 1998). Indeed, based on data collected in the field, in the past, given the fact that the bran and germs of wheat give a black color to bread, these two compounds have been reserved for livestock feed. The bread consumed at that time was only white bread. But nowadays, given the fact that the goods made from the consumption of whole meal bread are traced in the literature and are strongly advised by an innumerable number of dieticians and researchers, its consumption is becoming more and more important. According to Curtet (1998), whole meal bread enriches our diet with fiber while reducing the number of calories ingested.

\subsubsection{Choice of places to buy bread and decision criteria}

With regard to places of purchase, mini-supermarkets were in the past the most popular places to buy bread because they were sold everywhere and more or less close to cities. The average score (4.1) transcribed in Table 5 confirms this. But nowadays, this trend has reversed in favor of very large supermarkets because they offer several varieties of bread. In the past, several households opted for the preparation of bread at home. But given the difficulties and the time involved in preparing bread, these practices are becoming more and more abandoned. This justifies the $23.3 \%$ drop between the differences in average score. Bakeries, on the other hand, remain as popular today as in the past. However, we note a slight decline in the number of households using bakery services. 
Table 5. Bread buying places

In the past $(\%)$

Currently (\%)

Average

difference

\begin{tabular}{|c|c|c|c|c|c|c|c|c|c|c|c|c|c|c|c|}
\hline & 1 & 2 & 3 & 4 & 5 & $\mathbf{N}$ & Mean & 1 & 2 & 3 & 4 & 5 & $\mathbf{N}$ & Mean & 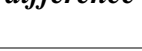 \\
\hline Bakery & 15,4 & 7,0 & 11,2 & 14,8 & 25,1 & 100,0 & 3,8 & 9,3 & 18,6 & 13,3 & 13,3 & 45,3 & 100,0 & 3,6 & $-5,3$ \\
\hline $\begin{array}{l}\text { Super } \\
\text { market }\end{array}$ & 56,6 & 11,3 & 5,6 & 13,2 & 13,2 & 100,0 & 2,1 & 4,6 & 17,1 & 7,8 & 10,9 & 59,3 & 100,0 & 4,0 & 90,5 \\
\hline $\begin{array}{l}\text { Mini super } \\
\text { market }\end{array}$ & 8,9 & 8,9 & 8,9 & 7,4 & 65,6 & 100,0 & 4,1 & 38,1 & 12,7 & 12,7 & 3,1 & 33,3 & 100,0 & 2,8 & $-31,7$ \\
\hline $\begin{array}{l}\text { Preparation } \\
\text { at home }\end{array}$ & 31,7 & 9,7 & 12,2 & 9,7 & 36,5 & 100,0 & 3,0 & 46,6 & 13,3 & 13,3 & 8,8 & 1,7 & 100,0 & 2,3 & $-23,3$ \\
\hline $\begin{array}{l}\text { Superette of } \\
\text { the town hall }\end{array}$ & 57,7 & 3,8 & 11,5 & 19,2 & 7,6 & 100,0 & 2,1 & 44,8 & 6,9 & 13,7 & 6,9 & 27,5 & 100,0 & 2,6 & 23,8 \\
\hline $\begin{array}{l}\text { From the } \\
\text { village }\end{array}$ & 42,8 & 7,1 & 14,2 & 17,8 & 17,8 & 100,0 & 2,5 & 24,2 & 27,2 & 18,1 & 12,1 & 18,1 & 100,0 & 2,7 & 8,0 \\
\hline Other & 50,0 & 8,3 & 2,7 & 5,56 & 33,3 & 100,0 & 2,6 & 36,1 & 13,8 & 8,3 & 5,5 & 36,1 & 100,0 & 2,9 & 11,5 \\
\hline
\end{tabular}

Several parameters guide consumers in choosing where to buy bread. All of its criteria as well as the scores assigned by consumers have been listed in Table 6. It appears from the analysis of the statistics obtained that the fact that the bread is fresh, that is to say the fact that 'it is prepared a few hours before its purchase is the first criterion for consumers' choice. This criterion remains the most important for consumers as well as today as in the past (4.7 in the past then 4.4 today). In fact, the fresher the bread the better its flavor then it keeps a crisp character. This quality is the most sought after by Adana consumers.

Table 6. Criteria for choosing the place of purchase

\begin{tabular}{|c|c|c|c|c|c|c|c|c|c|c|c|c|c|c|c|}
\hline & \multicolumn{7}{|c|}{ In the past (\%) } & \multicolumn{7}{|c|}{ Currently (\%) } & \multirow{2}{*}{$\begin{array}{c}\text { Average } \\
\text { difference }\end{array}$} \\
\hline & 1 & 2 & 3 & 4 & 5 & $\mathbf{N}$ & Mean & 1 & 2 & 3 & 4 & 5 & $\mathbf{N}$ & Mean & \\
\hline Price & 64,7 & 5,8 & 9,4 & 2,3 & 17,6 & 100,0 & 2,0 & 58,4 & 5,6 & 5,6 & 3,3 & 26,9 & 100,0 & 2,3 & 15,0 \\
\hline $\begin{array}{l}\text { Close to } \\
\text { home }\end{array}$ & 16,3 & 0,0 & 4,3 & 5,4 & 73,9 & 100,0 & 4,2 & 19,1 & 3,1 & 5,3 & 8,5 & 63,8 & 100,0 & 3,9 & $-7,1$ \\
\hline Fresh bread & 3,1 & 1,0 & 4,1 & 5,2 & 86,4 & 100,0 & 4,7 & 3,0 & 1,0 & 8,2 & 7,2 & 80,4 & 100,0 & 4,4 & $-6,4$ \\
\hline Hygiene & 6,3 & 10,6 & 13,8 & 5,3 & 63,8 & 100,0 & 4,1 & 2,0 & 6,2 & 9,3 & 7,2 & 75,0 & 100,0 & 4,0 & $-2,4$ \\
\hline Well done & 8,6 & 8,6 & 17,2 & 12,9 & 52,6 & 100,0 & 3,9 & 5,2 & 10,4 & 16,6 & 14,5 & 53,1 & 100,0 & 3,1 & $-20,5$ \\
\hline $\begin{array}{l}\text { Whole } \\
\text { wheat }\end{array}$ & 48,2 & 17,2 & 8,0 & 11,4 & 14,9 & 100,0 & 2,2 & 32,6 & 8,7 & 8,7 & 14,1 & 35,8 & 100,0 & 3,1 & 40,9 \\
\hline $\begin{array}{l}\text { Must be } \\
\text { lifted }\end{array}$ & 56,7 & 17,5 & 13,5 & 5,4 & 6,7 & 100,0 & 1,88 & 42,3 & 16,6 & 20,5 & 6,4 & 14,1 & 100,0 & 2,3 & 22,3 \\
\hline
\end{tabular}

Like the previous parameter, hygienic conditions are also important for consumers. Consumers being concerned about their health and that of their household, the fact that the bread is prepared in good hygienic conditions remains for them a very important criterion. According to Dubois-Brissonnet \& Guillier (2020), hygiene is a very important parameter in culinary sciences. Despite the importance of this criterion for consumers, there is nevertheless a slight drop of $2.4 \%$ between the scores means. This is justified by the fact that hygienic conditions are nowadays very respected; which gives consumers confidence. The trust placed by consumers in the various actors in the bread production and marketing chain, makes hygiene an increasingly less important criterion.

Table 7. Mode of serving bread during meals

\begin{tabular}{lrrr}
\hline & In the past (\%) & Currently (\%) & Average difference \\
\hline Thin slices & 15,0 & 27,0 & 80,0 \\
\hline Thick slices & 15,0 & 18,0 & 20,0 \\
\hline Large pieces & 16,0 & 12,0 & $-25,0$ \\
\hline Whole & 54,0 & 43,0 & $-20,4$ \\
\hline Total & 100,0 & 100,0 &
\end{tabular}

A particular zoom was also made on the modes of serving bread during meals (Table 7). Analysis of the results shows that the mode of serving bread in Adana's households has changed considerably over time. Nowadays, unlike the past, bread is much more served in thin slices, rather than whole. An increase in the share of households serving sliced bread (thin and thick) during meals was noted $(80 \%$ and $20 \%)$. In addition, it should be noted that there is a decline of $25.0 \%$ and $20.4 \%$ respectively in the share of households opting for the service of bread in large pieces and whole during meals. Currently, bread seems to be much more served in thin slices (27\% of households). This approach makes it possible to better assess the quantity of bread consumed and to avoid possible waste of bread.

\subsection{Consumer perceptions related to bread consumption}

In order to better understand the use of Adana households for the consumption of bread, their perceptions were also the subject of this study. From the results obtained, it appears that the perceptions collected revolve mainly around parameters such as: the unit sale e-ISSN: 2148-2683 


\section{Avrupa Bilim ve Teknoloji Dergisi}

price of the bread, the level of satiety, the nature of the meal it accompanies as well as the place of preparation of the bread. On the basis of these different parameters, proposals were formed and the respondents were asked to assign scores on the scale of 1 to 5 .

In the past, the unit selling price of bread was a very important criterion, in the sense that its unit selling price was more or less high and therefore reserved only for a single share of the population. But nowadays thanks to policies developed by the Adana City Council, this price has dropped considerably and bread has been introduced as the staple food of almost all households, especially that of low-income households. This justifies the drop of $13.3 \%$ recorded in the statistics obtained (Table 8 ).

Table 8: Consumer perceptions

\begin{tabular}{lrrr}
\hline \multicolumn{1}{c}{ Perceptions } & In the past (\%) & Currently (\%) & Average difference \\
\hline Bread is the cheapest food & 4,5 & 3,9 & $-13,3$ \\
\hline $\begin{array}{l}\text { When I don't eat bread during my } \\
\text { meals, I don't feel full }\end{array}$ & 3,7 & 3,0 & $-18,9$ \\
\hline $\begin{array}{l}\text { I eat all the bread served during my } \\
\text { meals in the fast food and restaurant }\end{array}$ & 4,2 & 3,8 & $-9,5$ \\
\hline $\begin{array}{l}\text { I eat all the bread served during my } \\
\text { meals in the fast food and restaurant }\end{array}$ & 2,3 & 2,6 & 13,0 \\
\hline $\begin{array}{l}\text { I also eat bread with dishes like rice } \\
\text { and pasta }\end{array}$ & 3,1 & 2,6 & $-16,1$ \\
\hline $\begin{array}{l}\text { I prefer the bread prepared in the } \\
\text { village to that made in the city }\end{array}$ & 3,7 & 3,8 & 2,7 \\
\hline
\end{tabular}

Like the unit selling price, the level of satiety when accompanying meals with bread was also mentioned. At the time, bread was a food always consumed at the table, regardless of the meal it accompanied. But today, unlike the past, there are many more educated people with higher levels of education. Thus, the consumption of bread is limited to a certain number of meals. This result confirms the results in Table 1 that unlike in the past, the consumption of bread has literally decreased.

In the past, reaching the feeling of satiety during meals amounted to consuming the bread in its entirety at the expense of the meal it accompanied. In other words, to feel full, Adana households opted to consume all the components of the bread. But these days things seem to be reversed. The mile of the bread (inside the bread) is consumed much less than enough is consumed the main meal at the expense of all the components of the bread is rather seen as better ways to wait for the satiety threshold. This therefore raises a problem of wasted bread. The observations made today in fast food restaurants in downtown Adana are a perfect example. This justifies the $13.0 \%$ increase noted in Table 8 .

\subsection{Factors influencing the consumption of bread}

A linear regression analysis was performed to study the variables that can affect consumers' bread consumption (in the past as in the present). In this analysis, the relationship between the total number of breads currently consumed and the total bread consumed in the past was taken as the dependent variable. Bread varieties (white, whole wheat, bread imported from the village, pide-lavash, tostsandwich, tandir-yufka), level of education, profession, age and monthly income were considered as variables independent (Table 9).

Table 9. Results of estimates from the linear regression model

\begin{tabular}{|c|c|c|c|c|c|c|}
\hline \multicolumn{2}{|l|}{ Variables } & Coefficient & Std error & $\mathbf{t}$ & $\mathbf{P}$ & VIF \\
\hline \multicolumn{2}{|l|}{ Constant } & 1,123 & ,414 & 2,709 & ,016 & \\
\hline \multicolumn{2}{|c|}{ Level of education } &,- 224 & 101 & $-2,226$ &, $042 * *$ & 2,107 \\
\hline \multicolumn{2}{|l|}{ Profession } & 240 & 109 & 2,211 & $043 * *$ & 1,847 \\
\hline \multicolumn{2}{|l|}{ Age } &,- 008 & ,004 & $-2,195$ &, $044 * *$ & 1,641 \\
\hline \multirow{3}{*}{$\begin{array}{l}\text { Bread } \\
\text { varieties }\end{array}$} & Whole wheat (In the past) &, 123 & 041 & 3,030 &, $008 * * *$ & 1,901 \\
\hline & Pide -Lavash (Currently) &,- 099 &, 047 & $-2,126$ &, $050 * *$ & 1,879 \\
\hline & Tandir - Yufka (Currently) & ,093 & ,032 & 2,927 &, $010 *$ & 1,281 \\
\hline
\end{tabular}

\section{Number of observation $=\mathbf{1 0 0}$}

$\mathbf{F}=3.52$

Prob $=0.015 * *$

$\mathbf{R}^{2}=\mathbf{0 . 6 6 7}$

***: significant at the $1 \%\left(\mathrm{P}_{-} 0.01\right)$; **: significant at 5\% $\left(0.01<\mathrm{P}_{-} 0.05\right)$; *: Significant at $10 \%\left(0.05<\mathrm{p} \_0.10\right)$.

Source: Results of estimates made with SPSS

The $\mathrm{R}^{2}$ obtained for the model is 0.667 . Therefore, the variables included in the model explain the level of bread consumption by households in Adana at $66.7 \%$. The regression model obtained is globally significant at the 5\% threshold, since the value of probability $\mathrm{p}$ in the table is less than 0.05 . In addition, the $\mathrm{R}^{2}$ of the regression being greater than $65 \%$, it is therefore considered to be sufficiently high.

In the model, variables such as level of education, occupation, age, preference for varieties of whole wheat bread, preference for pide-lavash bread (currently) and preference for tandir- yufka (currently) are significant (p values are less than or equal to 0.05). 
Therefore, depending on the coefficients obtained for each variable, it can therefore be deduced that the higher the education level of household members, the less the consumption of bread. In addition, it has been observed that the consumption of bread varies by profession. Civil servants, unlike farmers and merchants, have the lowest levels of bread consumption. The data collected made it possible to justify the high level of consumption of bread by farmers and merchants by the work and activities with which they are confronted. Farmers and merchants, unlike government officials (private and public organizations), engage in more intense physical activities. Agricultural production requires significant physical effort (Nourani, 2013).

Like the level of education, the level of bread consumption also decreases with age. Age is also a variable having a significant influence on the level of bread consumption of people in households. Young people, unlike the elderly, are attracted to the consumption of bread with each meal. In addition, unlike the elderly, they very often frequent university restaurants and fast food restaurants where bread is very often freely available and available in large quantities. According to the Swiss Nutrition Society (SSN, 2011), fast foods are part of major bread consumption points in the sense that they accompany almost all meals. Elderly people, concerned about their health, opt for a diet limiting the consumption of bread. Reducing the level of bread consumption limits the risks linked to a good number of diseases, in particular that linked to obesity and cardiovascular diseases (Lang, 2004).

It is observed that those who have developed a habit for the consumption of whole wheat bread have increased their consumption of bread today. At the same time, we observe that the consumption of pide-lavash bread has not decreased. The consumption of tandir-yufka has increased. These variations can be explained by the level of accessibility of these varieties of bread in terms of price and positioning. Consumers' perceptions of these different varieties of bread can also influence their level of consumption. Note that monthly income has no effect on the consumption of bread.

The graph below represents the plot "normal P-P" of the residues, and we can see that the residues are distributed near the right (Graph 1). Consequently, there is no distortion in the assumption of normality. The linear model is therefore valid.

Graphe 1. Normal P-P plot of regression standardized residual

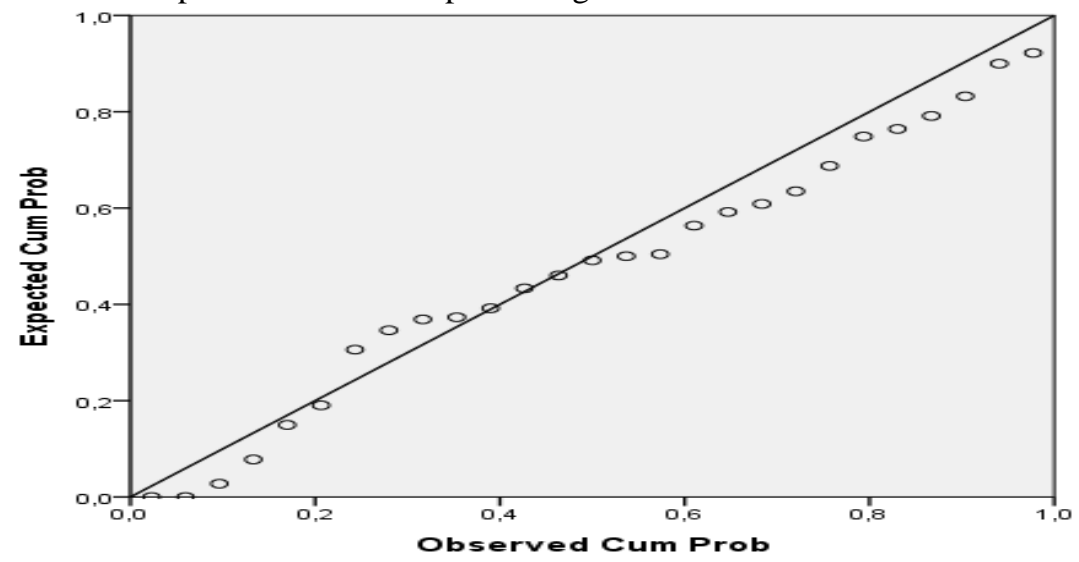

\subsection{Effect of price variations on the consumer's willingness to purchase}

The effect of the price change on the consumer's willingness to buy was assessed by the consumer's decision to buy whole wheat bread, although $5 \%$ expensive.

A logistic regression analysis was performed to determine which factors play an important role in the consumer's decision to buy whole wheat bread, although 5\% expensive. This decision by the consumer representing the dependent variable was introduced as in binary form taking the value 1 if the consumer answers with " yes " and by 2 if he answers with " no ". In this model, variables such as education, occupation, monthly income, household size and age were considered as independent variables.

The model estimates that the probability of a consumer buying whole wheat bread, although $5 \%$ expensive, is only 0.74 . In other words, there is a $74 \%$ chance that the consumer will agree to buy whole wheat bread or not. This producer decision is significantly influenced by the monthly income and the size of the consumer's household (Table 11). When whole wheat bread is expensive by $5 \%$, we find that as the size of the household increases, the consumer does not agree to buy the bread (1.86 times). In fact, the larger the household size, the higher the demand for bread consumption. As a result, an increase in the unit price of whole wheat whole meal bread negatively influences the consumer's decision to buy the bread. However, an increase in monthly income is likely to increase the probability that consumers buy bread, albeit expensive, by $0.36 \%$ by $5 \%$ (Table 11 ). An increase in the purchasing power of the consumer will therefore facilitate their access to whole wheat whole meal bread. In fact, the more you can buy goods and services with your income, the higher the purchasing power (Banque Française, 2020). According to the Senate (2006), the increase in consumer income also improves their purchasing power. This justifies the result obtained. 
Table 10. Estimated accuracy rate (a)

\begin{tabular}{|c|c|c|c|c|}
\hline \multirow[t]{3}{*}{ Variable } & & \multicolumn{3}{|c|}{ Description } \\
\hline & & \multicolumn{2}{|c|}{$\begin{array}{l}\text { I will buy wholemeal bread, } \\
\text { although } 5 \% \text { expensive }\end{array}$} & \multirow[t]{2}{*}{$\begin{array}{r}\text { Accuracy } \\
\text { rate }\end{array}$} \\
\hline & & Yes & No & \\
\hline \multirow{2}{*}{$\begin{array}{l}\text { I will buy wholemeal bread, } \\
\text { although } 5 \% \text { expensive }\end{array}$} & Yes & 62 & 5 & 92,5 \\
\hline & No & 20 & 11 & 35,5 \\
\hline General accuracy rate & & & & 74,5 \\
\hline
\end{tabular}

Table 11. Estimation of the logistic regression model (a)

\begin{tabular}{lrcrrrr}
\hline & Coeficient & $\begin{array}{c}\text { Std } \\
\text { error }\end{array}$ & Wald & Sd & P & $\operatorname{Exp(B)}$ \\
\hline Monthly income & $-1,019$ &, 269 & 14,340 & 1 & 0,000 & 0,361 \\
\hline Household size & 0,621 &, 263 & 5,579 & 1 & 0,018 & 1,861 \\
\hline
\end{tabular}

Table 12. Estimated accuracy rate (b)

\begin{tabular}{|c|c|c|c|c|}
\hline \multirow[t]{3}{*}{ Variable } & & \multicolumn{3}{|c|}{ Description } \\
\hline & & \multicolumn{2}{|c|}{$\begin{array}{l}\text { I will buy wholemeal bread, } \\
\text { although } 10 \% \text { expensive }\end{array}$} & \multirow[t]{2}{*}{ Accuracy rate } \\
\hline & & Yes & No & \\
\hline \multirow{2}{*}{$\begin{array}{l}\text { I will buy wholemeal bread, } \\
\text { although } 10 \% \text { expensive }\end{array}$} & Yes & 56 & 6 & 90,3 \\
\hline & No & 17 & 19 & 52,8 \\
\hline General Accuracy rate & & & & 76,5 \\
\hline
\end{tabular}

\section{Source Estimation made from SPSS}

Table 13. Estimation of the logistic regression model (b)

\begin{tabular}{lrrrrrr}
\hline & Coeficient & Std error & Wald & Sd & P & Exp(B) \\
\hline Monthly income & $-1,122$ &, 264 & 18,089 & 1 &, 000 & 0,326 \\
\hline Household size &, 872 &, 263 & 11,015 & 1 &, 001 & 2,392
\end{tabular}

As in the previous case, this new producer decision criterion is significantly influenced by the consumer's monthly income and household size (Table 13). When whole wheat bread is expensive by $10 \%$, on the fact that as the size of the household increases, the consumer does not agree to buy the bread (2.39 times). In fact, the larger the household size, the higher the demand for pain consumption. As a result, an increase in the unit price of whole meal bread negatively influences the consumer's decision to buy bread. However, an increase in monthly income is likely to increase the response that consumers buy bread, although expensive, by $0.32 \%$ by $10 \%$ (Table 13 ).

Income being a determining variable in the decision-making process in the purchase of bread by the consumer, a simple linear regression model was performed between monthly income and the total quantity of bread consumed.

The model produced is written in the form $y=b+a x, y$ represents the daily consumption of bread (number of baguettes), $b$ the constant then $x$ monthly income of the consumer. Consequently, the consumption of bread (y) is equal to the product of $3,402-8,54 \mathrm{E}-$ 05 by the monthly income of the consumer.

The regression equation is therefore expressed as follows: $\mathrm{y}=3,402-8,54 \mathrm{E}-05 *$ monthly income.

Thus, an increase in monthly income of $1,000 \mathrm{TL}(\simeq \$ 162)$ will cause the household's demand for bread to fall by $0.085 \%$. From this it is deduced that the demand for bread increases in low income groups. This is explained by the fact that bread is the staple food of low-income groups. Although slightly, as monthly income increases, the demand for bread decreases. As a threshold value, we can say that the demand for bread decreases as the monthly income of the consumer reaches 39,836 TL $(\simeq \$ 6,465)$ and then stops. Highincome consumers therefore opt for a form of food that considerably reduces the amount of bread consumed.

\section{Conclusion}

For several decades, bread has been the staple food of many households in downtown Adana. Although the average daily consumption level has dropped by $13.35 \%$. The importance of this food is most evident in low-income households as well as large families. This comparative study led to the conclusion that several changes have taken place over time in terms of consumer attitudes and behaviors. These changes are mainly related to the quantity of bread consumed, the types of bread consumed, the places of 


\section{European Journal of Science and Technology}

purchase, consumer perception as well as the criteria guiding consumers in the choice of places to buy. The consumption of bread is mainly influenced by the level of education, the profession, the age of the consumer, the unit-selling price of the bread as well as the preference for the different varieties of bread.

\section{References}

AAC. (2014). Le consommateur japonais: Comportements, dispositions et perceptions à l'égard des produits alimentaires AgriRéseau. https://www.agrireseau.net/documents/80371/le-consommateur-japonais-comportements-dispositions-et-perceptions-a1_egard-des-produits-alimentaires

Anonymous, (2016). AIBI Bread Market Report 2013, January. http://www.aibi.eu/wpcontent/uploads/draft-AIBI-BreadMarket-report-2013.pdf.

Aksoylu, Z., Savlak, N. Y., Yangic Ç., Cagindi, O., \& Kose, E. (2004). Manisa il merkezinde bireylerin ekmek çeşitlerini tüketim alişkanliklarinin belirlenmesi. GIDA, 39(3), 147-154.

Banque Française. (2020, janvier 17). La mesure du pouvoir d'achat. Banque de France. https://abc-economie.banque-france.fr/lamesure-du-pouvoir-dachat

Baysal, A. (2011). Beslenme. Yenilenmiş 13. Baskı. Hatiboğlu Yayınevi, Ankara.

Bouteldja, A. (2014). Analyse du secteur boulangerie-pâtisserie-viennoiseries. 48.

Curtet, R. (1998). Pain blanc, pain complet : Fabrication et intérêt diététique. 137.

Delgado, L. (1999). 20. Transfert du modèle de consommation alimentaire occidental ou innovation? In J.-P. Chauveau, M.-C. Cormier Salem, \& É. Mollard (Éds.), L'innovation en agriculture (p. 343-359). IRD Éditions. https://doi.org/10.4000/books.irdeditions. 15807

Dogan, I.S., 2003. Tahıl İşleme Teknolojisi. Yüzüncü Yıl Üniversitesi Ziraat Fakültesi Gıda Mühendisliği Bölümü Ders Notu, Van.

Dubois-Brissonnet, F., \& Guillier, L. (2020). Les maladies microbiennes d'origine alimentaire. Cahiers de Nutrition et de Diététique, 55(1), 30-38. https://doi.org/10.1016/j.cnd.2019.12.001

Erturk, A., \& Arslanta, N. (2015). Isparta İli Kentsel Alanda Ailelerin Ekmek Tüketimi ve İsrafi. Akademik Grda, 13(4), 9.

FAOSTAT.(2020). Quantité de production de blé par pays (Exemple de la Turquie). http://www.fao.org/faostat/fr/\#data/QC/visualize

Guine, R., Matos, M., Henriques, C. and Correia, P. (2016). Preferences and Consumer Habits Related to Bread in the Centre of Portugal. Nutrition \& Food Science, 46(3): 306-320.

Koten, M., Unsal, A.S., 2006. Şanlıurfa yöresine özgü tırnaklı ve açık ekmeklerin bazı kimyasal bileşimlerinin belirlenmesi üzerine bir araştırma. Harran Üniversitesi Ziraat Fakültesi Dergisi 10(3/4): 57-62.

Lang, T. (2004). Prévention des maladies cardio-vasculaires : Multifactorielle et multisectorielle ? ASDP, $n^{\circ} 47,51-55$.

Marty, P., Manceron, S., Le Mouel, C., \& Schmitt,B. (2015). Le système agricole et alimentaire de la région Afrique du NordMoyen-Orient : une analyse rétrospective (1961-2012). Synthèse du rapport rétrospectif de l'Etude « Le système alimentaire de la région Afrique du Nord - Moyen-Orient à l'horizon 2050 : projections de tendances et analyse de sensibilité ». DEPE, INRA.33.

Nourani, A. (2013). Etat de l'Art de la Mécanisation de la Phoenicilculture. 15. https://doi.org/10.13140/2.1.3905.8246

Padilla, M. (2001). Évolution des modèles de consommation méditerranéens : Akdeniz İ.I.B.F. Dergisi, 1, 2219-2226.

Senat. (2006). L'évolution du pouvoir d'achat des ménages : mesure et perception. Service des Études économiques et de la Prospective Délégation pour la planification.8. https://www.senat.fr/commission/planification/notes/evolution_pv_achat.pdf

SSN.(2011).Les plats rapides s'intègrent à une alimentation saine. Société Suisse de Nutrition. 6. http://www.sgessn.ch/media/feuille_d info_fast food_2011.pdf

TUIK. (2020). Institut statistique de Turquie. http://www.tuik.gov.tr/Start.do

Uzundumlu, A.S., Yildirim, B. Z., \& Kurtoglu, S. (2018). Erzurum ilinde ekmek tüketimini etkileyen faktörlerin belirlenmesi. The Journal of Academic Social Sciences, 77(77), 17-31. https://doi.org/10.16992/ASOS.14023 